\title{
THE REPUBLICAN DICTATORSHIP: AN IMPERIAL PERSPECTIVE
}

\author{
Christopher Burden-Strevens
}

\begin{abstract}
This chapter proposes to look at one of the less studied aspects of Cassius Dio's narrative of the decline of the Republic, namely the dictatorship. It argues that, in keeping with his especial interest in the Republic's institutions and constitutional framework, Dio believed that the collapse of the res publica and emergence of Augustus' Principate was intimately connected to the failuresconstitutional, practical, and reputational-of Rome's emergency magistracy. It shows that as a monarchist, Dio believed that the Republic could only survive intact while it had a temporary recourse to legitimate and temporary monarchy under restrictions agreed by the communitydictatorship-and that this view perhaps emerges more from a reading of Cicero than from his fellow Greek historians. However, the failure of the dictatorship to inspire confidence in the wake of Sulla, especially in the $60 \mathrm{~s}$ and $50 \mathrm{~s} \mathrm{BCE}$, as well as its practical and legal restrictions, led to a greater number of corrosive extraordinary commands and other destructive innovations. The solution, for Dio, ultimately lay in Augustus, who (like Pompey) recognised the flaws in the dictatorship and found different ways to define his power.
\end{abstract}

\section{INTRODUCTION}

The consular elections of 54 were a chaotic affair even by Late Republican standards, and represent a critical turning point in Roman constitutional history.' Arguably, genuine Republican government had already ceased to function six years previously with the threeheaded monster; but the actual collapse of Republican institutions must be credited to the latter half of the 50s. ${ }^{2}$ After many delays, by mid-October 54 all four candidates for the consulship of the following year had been charged with bribery. ${ }^{3}$ One of the hopefuls, C. Memmius, confessed in the Senate that he and another candidate had formed a secret agreement with the incumbent consuls, Cato and Ahenobarbus: these were to support Memmius' candidacy in return for juicy consular provinces if he should be elected. Memmius' confession was (allegedly) instigated and encouraged by Pompey. ${ }^{4}$ Attempts by the interreges to hold the comitia were checked by unfavourable omens and deliberate obstruction by tribunes. ${ }^{5}$ Amid this crisis rumours were circulating of a plan to appoint Pompey as dictator, evidently with the support of the newly-elected tribune for 53, C. Lucilius Hirrus. ${ }^{6}$ This did not come to pass. Plans for a dictatorship for Pompey fell through: some time earlier in 53 he declined the office, and Cn. Domitius Calvinus and M. Valerius Messalla Rufus finally entered office in the

I wish to thank, in particular, Josiah Osgood (Georgetown) for his helpful suggestions on an earlier draft of this paper, and especially for drawing the important article of John Ramsey to my attention. I am also grateful to Chris Baron (Notre Dame) for his corrections and comments, and to Kathryn Welch (Sydney) for her guidance on the controversies surrounding Brutus' coinage, which I have included (cautiously) below.

${ }^{1}$ So Arena 2012 1, n.2.

'Hence Cicero's grim allusion in April 54 to Pompey's supposed 'list' of planned future consuls at Att. 4.8a.2. Steel 2013, 183 is right to treat this with a little scepticism, although compare App. B.Civ. 2.19 on the events of the same year: 'the consuls holding office yearly could not hope to lead armies or to command in war because they were shut out by the power of the triumvirate'.

${ }_{3}^{3}$ Cic. Att. 4.18.3. Previously only three were implicated: see Att. 4.17. For the candidates, see Gruen 1969.

${ }^{4}$ Cic. Att. 4.17.2-3.

Cass. Dio 40.45.3.

${ }^{6}$ Cic. Q. Fr. 3.8.4-6, 3.9.3; Plut. Pomp. 54.2-3. 
summer of that year, when the contest for the next year's appointments was already underway. That is not to say that Pompey emerged from the crisis of the preceding two years emptyhanded, however: a compromise, seemingly orchestrated by the interrex Servius Sulpicius, had Pompey elected by the people (not 'appointed' by the Senate, so it seems) to the sole consulship for 52 with senatorial consent. ${ }^{8}$ He entered office on the $24^{\text {th }}$ day of the intercalary month between February and March.

To this point our main surviving sources for this crisis-Appian, Asconius, Cassius Dio, Cicero, and Plutarch-are broadly in agreement. The real controversy emerges with Pompey's role in the episode and his motivations, especially regarding the dictatorship. According to Appian, Pompey was eager for the honour in 54-53 and indeed 'deliberately oversaw events'

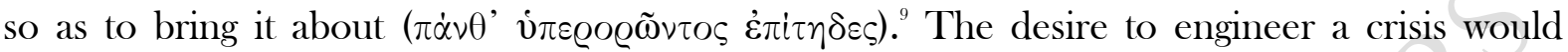
certainly explain Pompey's eagerness for Memmius to confess publicly his scandalous pact with Cato and Ahenobarbus. Appian alleges that Pompey deliberately postponed the comitia to exert the maximum damage, all the while publicly making a show of rejecting the dictatorship. ${ }^{10}$ For Appian and also Plutarch," Pompey's scheming was only scotched by Cato and Bibulus

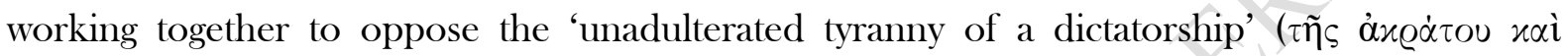
$\tau \cup \varrho \alpha \nu v\left(x \tilde{\eta}_{S} \dot{\varepsilon} x \varepsilon i \nu \eta \varsigma\right)$ and proposing the consulship sine collega as an innovative-but not unpalatably radical-compromise. ${ }^{12}$ They maintain that Pompey's desire for the dictatorship was consistent throughout and his refusals a sham: ${ }^{13}$ evidently he willed it in late 54 , through 53 , and even early in 52 (hence Cato and Bibulus' proposal). But in so doing they conflate the situation in late 54, when there were consuls in office, with 53 and 52, when there were not. In 54 an appointment to the dictatorship was possible in the regular way, by the incumbent consuls $e x$ senatus consulto. In 53, on the other hand, this was quite impossible; the only (understandably unattractive) option would be to revive the precedent of Sulla in an extraordinary appointment to the dictatorship by an interrex. ${ }^{14}$

Cassius Dio's take on the crisis is quite different. Dio's Pompey emerges as the saviour of the electoral debacle of 54-53. Voluntarily declining the dictatorship in 53 upon returning to Rome, he takes pains to have Calvinus and Messalla Rufus elected, and in his sole consulship acted in accordance with the wishes of the Senate by eschewing the temptation to rouse an already excited plebs. ${ }^{15}$ In a touch that is entirely Dio's invention, Pompey is even made to detest the prospect of a consulship sine collega (!): 'he did not wish to hold office alone; for now that he had the glory that lay in the passing of such a vote, he wished to avoid the envy

Cass. Dio 40.45.1 writes that Calvinus and Messalla were elected in the seventh month, but App. B.Civ. 2.19 in the eighth.

${ }^{8}$ See Ramsey 2016 for an excellent recent discussion of the circumstances surrounding Pompey's position as sole consul in 52. Our ancient sources suggest that the Senate arrogated to itself the authority to 'appoint' Pompey as sole consul, so Liv. Per. 107, Val. Max. 8.15.8, Plut. Caes. 28.7, App. B.Civ. 2.23.84, and Cass. Dio 40.50.4; modern historians have tended to follow this cue. Ramsey suggests (particularly from a reading of Asconius) that Pompey was in fact elected per interregem.

${ }^{9}$ App. B.Civ. 2.19.

${ }^{10}$ App. B.Civ. 2.20. This seems excessively cynical, but the recusatio is characteristic: see Vervaet 2010.

${ }^{11}$ Plut. Caes. 28.7.

${ }^{12}$ App. B.Civ. 2.23.1; for the quote, Plut. Pomp. 54.3. See Ramsey 2016, 308-318 for discussion of the ways in which the proposal may have been made acceptable to conservatives.

${ }^{13}$ So Meyer 1922, 210.

${ }^{14}$ See Ramsay 2016, 309: 'Pompey may well have found the dictatorship less appealing in 53 than he did in the latter half of 54, when his appointment could have been made in the time-honoured, non-Sullan manner by one of the consuls still in office. Vervaet 2020, 155-59...fails to distinguish between conditions in 54, when consuls were still in office, as compared with 53 and 52 , when the consulship was vacant'.

${ }^{15}$ Cass. Dio 40.46, 40.50. 
associated with it'. ${ }^{16}$ The desire to keep Caesar out of office emerges as a secondary motive on his part in Dio; this is unlikely to have been a real concern at this point in 52, since Caesar had a certain Vercingetorix to deal with. Dio's Pompey is, in other words, made to adopt (certainly) someone else's philosophical justification for a 'Republican' course of action he (probably) did not intend. Perhaps the historian's positive view of the general here may be inspired by Cicero. In a letter of November 54, Cicero is equivocal about Pompey's intentions, and writes that his public disavowal of a dictatorship, about which rumours had evidently been circulating at least since June, was inconistent: when asked in private, he couldn't deny wanting it (Pompeius plane se negat velle; antea mihi ipse non negabat). ${ }^{17}$ But here again we need to differentiate between the situation in late 54, when a dictatorship was possible in the regular fashion, and that of 53, when it was not. Dio's interpretation of Pompey's motivations is highly distinctive; very much unlike Appian and Plutarch, he believed that his refusal in 53 was genuine.

Our historian's view of Pompey's attitude to a sole consulship may not convince, but the interpretation of his hopes for a dictatorship in 53 (or rather lack thereof) merits serious consideration. The evidence discussed below shows that it was evidently a discredited political solution, and anxieties about the office in general-and not only in connection with Pompeyappear to have been shared by a wider contingent than Cicero alone in 54-53. What we have here appears to be a deliberate choice on the historian's part to deviate from a quite uniform tradition regarding the general's ambitions for a dictatorship. It cannot be discounted that this emerges from his use of alternative sources, of course, but this will not bear fruit. For a start, the consistency of the extant accounts makes a deviant tradition guesswork: Appian, Cicero, and Plutarch all suggest that Pompey had a dictatorship in his sights. Moreover, Dio had access to these sources. ${ }^{18}$ He seems to be forming a different interpretation on his own initiative.

Why make such a radical departure? This chapter proposes that Cassius Dio was especially preoccupied with the problematic nature of the Republican dictatorship as an exercise of powers. Pompey's disavowal of that office and the honour he is paid as a resultwhich Dio frames uniquely as a genuine and more importantly astute political manoeuvre-is only one episode in a much wider exploration of the role played by the dictatorship in the fall of the Republic. Dio argues that by the first century BCE the dictatorship had become wholly unsuited to the needs of government: it was ineffective in practical terms as well as being politically toxic. Pompey's handling of the crisis of 54-53 showed his awareness of this fact, and so his political acumen; Caesar failed to observe this lesson, with fatal consequences. Yet at the same time, the historian firmly believed in the value of autocracy and the stabilising power of sole rule in times of upheaval. ${ }^{19}$ The statesmen of the Roman History are thus caught in a bizarre paradox, a different 'crisis without alternative': ${ }^{20}$ autocracy was needed to save the Republic, and yet could no longer operate within the traditional framework. The resolution to that paradox was Augustus.

The first part of this chapter sketches out Cassius Dio's view of the proper role of the Roman dictatorship, focussing on his commentary on its alleged foundation at the turn of the

\footnotetext{
${ }^{16}$ Cass. Dio 40.51.1. The contrast between the $\varepsilon \hat{v} x \lambda \varepsilon\llcorner\alpha$ of a voluntary grant of magnificent powers and the $\varphi \theta \dot{\text { ovo }}$ attached to those powers is a paraphrase of Dio's speeches on the lex Gabinia (36.25.3-26.2), and the antithesis is made umpteen times elsewhere.

${ }^{17}$ Cic. $Q$. Fr. 3.8.5.

${ }^{18}$ On Dio and Cicero, see Burden-Strevens 2018. For discussion of Dio and Appian, see Gowing 1992. Dio's relationship with Plutarch is less charted: Millar 1964 believes that references to Plutarch are Zonaras' interpolation.

${ }^{19}$ At 44.2.1-5, Cass. Dio states gnomically that 'if ever' there was a noble $\delta \eta \mu o x \varrho \alpha \tau i \alpha$, it only endured for a short time. For this thought see also 30-35 F 110.2. At 53.19.1, he explicitly outlines his view that following the Augustan Settlement, the Roman constitution was changed for the better; it was manifestly no longer possible to keep the people safe under a $\delta \eta \mu о \varkappa \varrho \alpha \tau i \alpha$. For this attitude see Tac. Hist. 1.1.1, 1.16.1; Sen. Ben. 2.20.2; App. B.CIV. 4.133. See also Madsen 2016.

${ }^{20}$ Famously, Meier 1966; see also Rilinger 2007, 132-50.
} 
$5^{\text {th }}$ century BCE. Unlike other historians, Dio appears to have emphasised the positive potential of dictatorship as a temporary return to monarchy; his earlier books present numerous positive and successful examples of dictatorships in Republican history. However, this was not to remain. The next part explores Dio's presentation of the dictatorship in a 'second' phase, the period after Sulla, and shows that the historian problematised this office on both practical and moral grounds. He was not the first to do so; contemporary evidence from the 50s suggests the dictatorship as such was in disrepute, and not only in connection with Pompey. In that context, his view of Pompey's refusal as genuine (and astute) in 53 makes sense. Third and finally, this chapter briefly considers Dio's account of the earlier years of Augustus' principate in Books 52-54 and his own rejection of the dictatorship.

\section{PHASE ONE: THE IDEAL OF DICTATORSHIP}

Let us start at the beginning. Blessed with hindsight, Dio seems to have viewed the inauguration of the first dictator Titus Lartius in 501 (or 498) as a moment of great importance. ${ }^{21}$ Pausing his narrative of the Republic's early conflicts with the Sabines, Dio describes the institution of this office as a direct response to military and civic crisis: the indebted plebs, infuriated at their treatment by their patrician creditors, refused the draft when called upon to defend the Republic against the threat of the Latins, and demanded a cancellation of debts. ${ }^{22}$ Dio then goes on to review the dictator's formal powers: the six-month tenure, immunity from provocatio and intercession by tribunes, and-a detail absent in our other historians-certain restrictions on his right to draw from the treasury and on riding mounted in the city. The surviving text is Zonaras' epitome, not Dio's: although no fragments of this material survive in the direct tradition, we can be reasonably confident of Zonaras' faithfulness, and can treat these as authentic in an albeit abridged format. ${ }^{23}$

One of the most striking aspects of Dio's accont of Lartius' appointment as dictator is his view of its positive potential. Dio takes pains to stress the beneficial aspects of a temporary return to autocracy, especially during periods of instability:

...he possessed power equal in all respects to that of the kings. People hated the name of 'king' on account of the Tarquins, but desiring the benefit to be derived from sole leadership, which seemed to exert a potent influence amid conditions of war and revolution, they chose it under another name.

This is notably different from the accounts given in both Livy and Dionysius of Halicarnassus. In the former, Titus Lartius' appointment is treated as a cause for great apprehension: the terrified plebs, hard pressed with the sight of Lartius' fasces, had 'no hope of help from another, nor right of appeal, nor any safety anywhere except in obedience'. ${ }^{24}$ The patricians' rationale for instituting the office is to inspire fear and quell the plebeian struggle temporarily to deal with the Sabines and Latins, objectives in which they succeeded. Dionysius' account is

\footnotetext{
${ }^{21}$ Cassius Dio and Livy have 'Lartius'; for 'Larcius' see Cic. Resp. 2.32 and D.H. AR 5.73. 'Largius' is also attested.

${ }^{22}$ For the debate surrounding the historicity of the alleged 'First' Latin War, see Cornell 1995 and Forsythe 2005. This does not concern us here: like all annalists Dio believed the tradition.

${ }^{23}$ For Zonaras' faithfulness to Dio, see most recently Fromentin (forthcoming), who shows the epitomator's method of preserving acts of speech and retaining points of transition between speech and narrative. Simons 2009, 25-32 outlines Zonaras' methods with the narrative proper. Further in Mallan (forthcoming).

${ }^{24}$ Liv. 2.18.8: magnus plebem metus incessit, ut intentiores essent ad dicto parendum; neque enim ut in consulibus qui pari potestate essent, alterius auxilium neque prouocatio erat neque ullum usquam nisi in cura parendi auxilium.
} 
quite different. It is much more pessimistic and takes pains to associate dictatorship with monarchy in its degenerate form, tyranny. For Dionysius, the chief reason for a dictatorship was, above all ( $\dot{v} \pi \grave{\varepsilon} \varrho \ddot{\alpha} \pi \alpha \nu \tau \alpha)$, the supposed lex Valeria de provocatione: the Senate were seeking a specious mechanism 'by which to deceive the poor and, without being detected, repeal the law that secured their liberty ${ }^{25}$ In that vein, the historian describes the dictatorship repeatedly as a form of tyranny as such. Dionysius asserts baldly that a such a magistracy, being above the law, was a tyranny in fact if not by name: ${ }^{26}$ it is compared directly to emergency powers in (for example) Thessaly and Sparta, where tyrannical powers ungoverned by law and

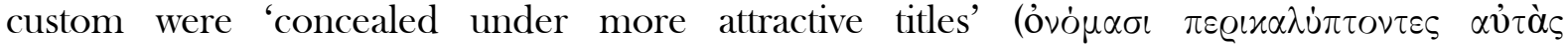
$\varepsilon \dot{\jmath} \pi \varrho \varepsilon \pi \varepsilon \sigma \tau \dot{\varepsilon} \varrho \circ \iota \varsigma){ }^{27}$ Viewing the events of 501/498 through the lens of the $1^{\text {st }}$ century BCE, Dionysius and to a lesser extent Livy present the dictatorship as a problematic institution from its inception.

Dio's view of the Republican dictatorship is in fact far closer to Cicero's than to that of his fellow-historians. Leaving aside its routine or ritual functions (clavi figendi causa, for example, or holding games), ${ }^{28}$ he evidently saw within the dictatorship the positive potential for a temporary resort to monarchy in times of crisis. Dio certainly did not wrongly believe (like Dionysius) that the dictatura was a form of tyranny by its nature. This is confirmed by his own commentary on the lex Antonia of $44 \mathrm{BCE}$, permanently abolishing that magistracy. He writes that the Romans took what they believed to be the best course for the future, as if the disgrace

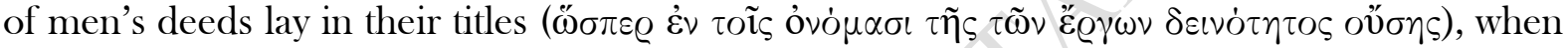
in fact-he corrects the statesmen of April 44 on their mistake-the issue was not the dictatorship as such, but the combination of military command and a tyrannical character. ${ }^{29}$ In other words, for our historian dictatorship was a legitimate mechanism for bringing stability to the state, with the temporary reality of monarchy but the necessary illusion of a civilian title. Whether this aspect of Dio's political thought was inspired by some intermediary is unclear, but its earliest (surviving) expression can be found in the Republic. Cicero's comment on the proper role of the dictatorship in the state is most clearly articulated in Book 2:

...and just as Tarquin subverted the whole fabric of royalty-not because he grasped a new sort of authority, but because he made a bad use of it-so let us oppose to him another: a good man, wise and expert in everything useful and dignified in civil life: a tutor and steward as it were of the commonwealth...Tarquin being banished, the royal title was as odious to the Roman people as it had been regretted after the death or rather the disappearance of Romulus; and as much as they wanted a king then, in like manner, after the expulsion of Tarquin, they could not endure the name of one...In these very times too, T. Larcius was appointed dictator, about ten years after the first consuls. A new kind of authority, very much resembling, as we perceive, the royal power. ${ }^{30}$

Now, the Republic is not without its difficulties. The text was written between around 54-51 BCE, when 'democratic' institutions had effectively collapsed; it accordingly presents an ideal, not the reality, and this is evidently not a guide to Roman politics in practice. It is significant

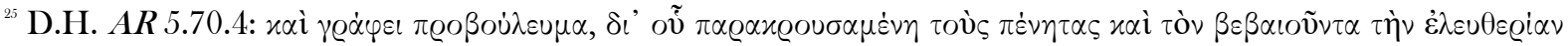

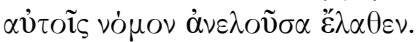

${ }^{26}$ D.H. AR 5.73.2: 'the extent of the power which the dictator possesses is by no means indicated by the title; for

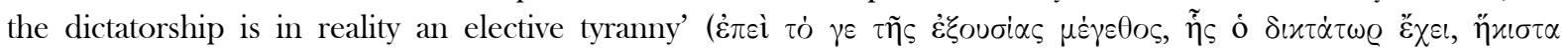

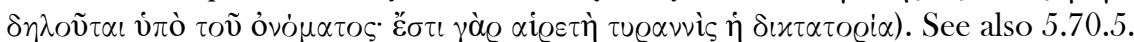

${ }^{27}$ D.H. $A R$ 5.74.1-4.

${ }^{28}$ On which Lintott 1999, $109 \mathrm{ff}$.

${ }^{29}$ Cass. Dio 44.51.2-3.

${ }^{30}$ Cic. Resp. 2.29-32.
} 
that Cicero may have been penning this book just when anxieties about a potential dictatorship for Pompey were at their height in late 54 and early 53. ${ }^{31}$ Furthermore, there are obvious inconsistencies in Cicero's attitude toward this magistracy if we look at his work in the round. Hence in a rare moment of praise for Antonius, the orator lauds his abolition of the dictatorship in the lex Antonia, 'which by this time had come to possess kingly power, ripped out of the state by its roots' ${ }^{32}$ Repeatedly he refers to the 'universally catastrophic dominatio and regnum of Sulla in victory'. In private, he wrote to Cassius that with Caesar's assassination Rome had been liberated not only from a king (non regno sed rege liberati videmur) but from a tyrannus, whose injuries against the Republic had been avenged with his death (ulta suas iniurias est per vos interitu tyrannt). ${ }^{34}$ Naturally in that light we need not put too much faith in Cicero's praise of Caesar in the Pro Deiotaro, describing the dictator as 'not only not a tyrant, but a most merciful man, ${ }^{35}$ It was addressed directly to Caesar himself!

Nevertheless, all of these critiques are concerned with the reality of the dictatorship in the final decades of the res publica as exemplified in its two most controversial holders, Sulla and Caesar. What they do not do is simplistically criticise (as Dionysius) the dictatorship in and of itself as a tyrannical institution; for were that the case, why persist with it regularly for over three hundred years? In other words, these comments of Cicero are not a general view of the dictatorship, but a castigation of its corruption and usurpation by two specific holders. Hence for the conception of what this office should be and how it was intended to function under usual circumstances, we have the dialogue on the commonwealth. The Republic asserts the positive potential of the dictatorship in the mind of a contemporary observer, and in terms that are remarkably similar to Dio's later. Both our historian and Cicero note the odium for the name of kingship after the expulsion of Tarquin, but emphasise that the Romans of the late $6^{\text {th }}$ century wanted a king all the same-hence, the dictator. Both also review the scope of the dictator's powers in positive terms, Dio highlighting the potential 'benefit' of a sole ruler for the state in periods of instability and war, and Cicero focussing on the benefit to be derived from 'a tutor and steward of the commonwealth'. In that regard, the role of the ideal statesman, the rector rei publicae, can apparently be fulfilled by the dictator appointed in a time of crisis; Dio, as a theorist in his own right of Republican institutions and their effect upon the practice of politics (see Coudry in this volume), was evidently receptive to this idea. ${ }^{36}$

Thus from its first appearance in the Roman History Dio seems to have presented the Roman dictatorship in a radically different light from our two other main historians of early Rome, Dionysius and Livy. Dionysius in particular chose to view that office from its foundation through the lens of events in the $1^{\text {st }}$ century BCE; this is plainly wrong and misleading. Our historian, in contrast, took a more measured approach. Like Cicero, he viewed the dictatorship as a temporary return to monarchical powers in the interests of the state, which was only corrupted by the individual ambitions of its most controversial holders-Sulla and Caesar. This, to reiterate, explains his commentary on the lex Antonia. The office itself was not the issue: ${ }^{37}$

But the consuls...published a law that no one should ever again be dictator, invoking curses and proclaiming death as the penalty upon any man who should propose or support such a measure, besides openly setting a price upon the heads of any such. This provision they made for the future, assuming that the shamefulness of men's deeds consists in the titles they bear, whereas these deeds

\footnotetext{
${ }^{31}$ Cic. Q. Fr. 2.12.1.

${ }^{32}$ Cic. Phil. 1.2: dictaturam, quae iam vim regiae potestatis obsederat, funditus ex re publica sustulit.

${ }^{33}$ Cic. Har. Resp., esp. 54: universus interitus aut victoris dominatus ac regnum.

${ }^{34}$ Cic. Fam. 12.1.1-2.

${ }^{25}$ Cic. Deiot. 34.

${ }^{36}$ For discussion of Cicero's rector rei publicae, see Zarecki 2014.

${ }^{37}$ Cass. Dio 44.51.2-3.
} 
really arise from their possession of armed forces and from the character of the

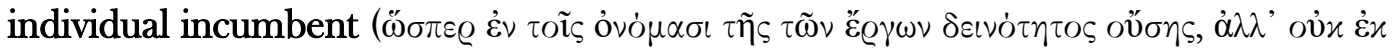

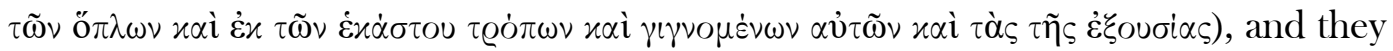
disgrace the titles of authority under which they chance to occur.

It is difficult to gauge how Dio's presentation of the dictatorship throughout most of its history related to his distinctively positive, 'Ciceronian' take on the office at the time of its foundation. The text is lacunose, and even Zonaras' epitome preserves little detail except on the most famous of Rome's dictators. But the information that survives gives an almost consistently positive account. The presentation of Cincinnatus' dictatorship is conventional: the farmhand who valiantly crushed Spurius Maelius' adfectatio regni, and so forth. ${ }^{38}$ Zonaras records that in 272 BCE the former dictator P. Cornelius Rufinus was removed from the senate roll for transgressing sumptuary legislation, but this is hardly a reflection on the dictatorship as such. ${ }^{39}$ Lucius Papirius Cursor (325 \& 310?) and Aulus Cornelius Cossus Arvina (322?) are described positively in connection with the Samnite wars. ${ }^{40}$ The war with Hannibal is naturally a chance to display Roman valour. Fabius Cunctator emerges in particular favour: his strategy is described as wise and effective, and it is his impetuous master of horse Rufus, not the delaying dictator, who is made the subject of criticism. ${ }^{41}$ The account of M. Junius Pera's efforts to rescue Rome as dictator in 216 is broadly approving, in particular his work to save the beseiged people of Basilinae from hunger and his controversial last resort (not criticised by Dio-Zonaras) of conscripting even slaves and criminals to face the threat of Hannibal. ${ }^{42}$ Finally, there is $\mathrm{M}$. Furius Camillus. Although Dio records anger at his decision to ride on white horses in his triumphal procession, ${ }^{43}$ the remaining detail of Camillus' several terms as dictator is laudatory: after being betrayed by his countrymen and going into exile, Camillus returns to quell the alleged conspiracy of Capitolinus and in a fifth dictatorship defeats the Gauls at the river Anio. Following his resignation in the proper term and his death, there was great public grief. ${ }^{4}$

These few episodes are all that remains of what must originally have been dozens of vignettes on the activities of Roman dictators between T. Lartius' inauguration and 202 BCE, when the office fell out of use. There is nothing here to support the conflation between dictatorship and tyranny-monarchy in its degenerate form-which we find in Dionysius. Instead, what we find in Dio's earlier history is a collection of examples consistent with his vision of the proper role of dictatorship in a functioning Republic: a legitimate and temporary return to monarchy in order to stabilise the state in times of desperate need.

\section{PHASE TWO: THE DICTATORSHIP IN CRISIS}

For Dio the final decades of the libera res publica represented the collapse of that vision. This is of course not surprising in view of the experiment with Sulla and Caesar; but the disappearance of the dictatorship as a viable exercise of powers in the first century BCE is in fact integral to his explanation of the crisis of the Republic and the emergence of Augustus' rule. This decline in the dictatorship from a genuine 'stewardship of the commonwealth' in Cicero's words to an unworkable and discredited failure is already alluded to by Dio from its first

\footnotetext{
${ }^{38}$ Cass. Dio 5 F 23.2, 6 F 20.

${ }^{39}$ Zon. 8.6.

${ }^{40}$ Zon. 7.26, Cass. Dio 8 F 36.26.

${ }^{4}$ Zon. 8.25-26.

${ }^{42}$ Zon. 9.2.

${ }^{43}$ Cass. Dio 6 F 21.

${ }^{4}$ Cass. Dio 6 F 24.4.
} 
appearance in the Roman History. To linger a moment longer on the inauguration of T. Lartius in Book $4:^{45}$

The office of dictator extended for a period of not more than six months, in order that no such official by lingering on in the midst of so great power and unhampered authority should become haughty and be carried away by a passion for sole leadership. This was what happened later to Julius Caesar, when, contrary to lawful precedent, he had been adjudged worthy of the dictatorship.

This commentary-if genuinely Dio's-is significant. The historian appears to have used the earliest formation of the dictatorship as an opportunity to reflect on the development of the office over time and to foreshadow its transformation in the final decades of the Republic. There is every possibility that the exemplum of Julius Caesar here is a later interpolation of the epitomator. Narrative techniques such as allusion, prolepsis, and analepsis are common in Dio's history, but these are usually far more oblique than this explicit exemplum. Nevertheless, exempla are common to Dio's compositional technique-especially of course in the speechesand the historian's particular interest in the role of the dictatorship within the Republic's permutations would certainly explain the choice to foreshadow Caesar's career at an early stage. The earlier portions of Dio's work present dictatorship in its proper form, adducing examples of the benefit provided to the state by a number of holders; the allusion to Caesar, on the other hand, points forward to the historian's argument about its degenerative role.

That argument at last arrives in explicit terms in Book 36 in the speech of Q. Lutatius Catulus. The ostensible rhetorical purpose of the speech is a long dissuasio against the lex Gabinia of 67 BCE, which proposed an extraordinary command of three years for an unspecified undividual over the entire Mediterranean to combat the threat of piracy. Dio notes that, naturally, there was no need for Gabinius as rogator to name Pompey for him to immediately spring to mind as the ideal candidate for the piratical command. But in truth-and as Marianne Coudry has correctly shown-the piratical menace is of little importance in Dio's staging of the debate. The historian's actual purpose is to use this setting as the springboard for an extended discussion of Republican politics, reflecting upon the corruption of political life and the state of the constitution in the wake of Sulla. ${ }^{46}$ It is in that context that we must place Catulus' comments on the dictatorship and can make sense of them. After his exordium, Dio's Catulus begins by criticising extended periods of command as illegal and corrosive to the res publica: no individual can abide by ancestral customs, such as collegiality and healthy competition for status, if entrusted with repeated positions of power. ${ }^{47}$ This, Dio argues, was precisely the problem with Marius and then Sulla: the latter became 'what he was' as a result of successive periods of command, first of armies in the field and then as dictator and consul. Interestingly, Catulus then reviews other possibilities: why give an extraordinary and unconstitutional command to Pompey rather than relying on existing consuls and praetors? Alternatively, Catulus argues, the dictatorship might even be used to resolve the menace of Mediterranean piracy. The passage is revealing, and worth quoting in full: ${ }^{48}$

But if it is indeed necessary to elect an official alongside the yearly magistrates, there is already an ancient precedent, that is, the dictator. However, our ancestors did not establish this office for every circumstance, nor for a period longer than six months. Therefore, if you do require such an official, it is possible for you to engage either

\footnotetext{
${ }^{45}$ Zon. 7.13.

${ }^{46}$ Coudry 2016.

${ }^{47}$ Cass. Dio 36.31.3-4.

${ }^{48}$ Cass. Dio. 36.34.
} 
Pompeius or any other man as dictator without transgressing the law nor failing to deliberate carefully for the common good-on the condition that this be for no

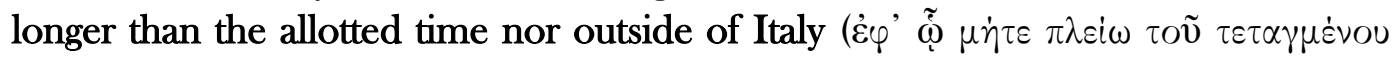

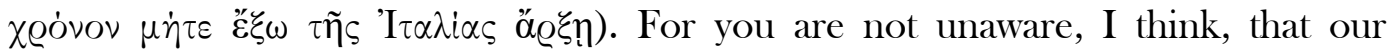
ancestors zealously preserved this limitation, and that no dictator can be found who served abroad, aside from one who went to Sicily and achieved nothing. But if Italy requires no such person, and if you cannot bear not only the function of a dictator

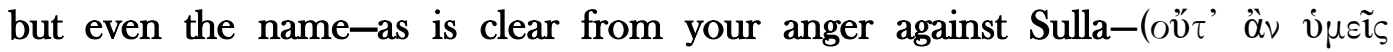

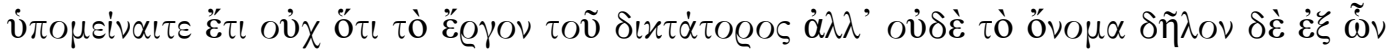
$\pi \varrho \grave{s} \tau$ òv $\left.\sum \dot{u} \lambda \lambda \alpha \nu \dot{\eta} \gamma \alpha \nu \alpha u \tau \dot{\eta} \sigma \alpha \tau \varepsilon\right)$ how could it be right to create a new position of authority over practically everything within Italy and outside it for three years? You all know what horrors come to states from such a course, and how many have often

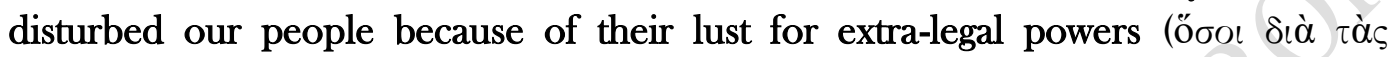

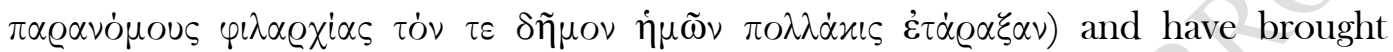
innumerable evils upon themselves.

At first glance these comments of Dio's speaker make little logical sense. Was the historian incompetent? ${ }^{19}$ In order to combat the threat of piracy across the Mediterranean-a complex military operation over a wide geographical area-Catulus proposes a dictatorship which is by its nature restricted. The dictator must not leave Italy, and should resign within six months as have all dictators hitherto. ${ }^{50}$ Moreover, these severe limitations are enumerated by the speaker himself. In other words, Catulus' suggestion is without worth in the context of 67 .

But Dio is not using Catulus to propose a genuinely workable alternative to an extraordinary command for Pompey. Rather, this interjection from Catulus is used to illustrate clearly by example that in a world empire, Romans of the Late Republic had little choice but to resort to dangerous extraordinary commands. Evidently-as Catulus shows-the dictatorship was wholly unsuitable as an emergency magistracy to address the exigencies of a large empire. The historian absolutely (and rightly) recognised that extended periods of command were corrosive to Republican traditions, engendering autocratic ambitions in those who received them; this is stated flatly by Catulus at the end of the excerpt. ${ }^{51}$ Yet crises occurred within a Republican empire just as in all empires: who could be tasked to address them if not the regular magistrates, limited by an impractical one-year term, or the dictator, limited by even more stringent restrictions? So far from dissuading the Quirites from choosing Pompey, Dio's Catulus merely reiterates that the existing framework furnished few other options. Dio clearly believed that 'democratic' empires were immoderate and susceptible to stasis, he says himself that the scope of the empire required a capable autocrat to guide it. ${ }^{52}$ Within the framework of traditional liberty, this individual was the dictator-'a ruler under another name', in Cicero's and later Dio's definition-yet this was no longer a practical option.

\footnotetext{
${ }^{49}$ Evidently not; the oblique reference to an unsuccessful dictator in Sicily is Aulus Calatinus (see Cass. Dio 12. F 15), dictator in 249 BCE. Obviously Dio had done his research to insert this rather neat historical detail, and the recall suggests hypomnemata of particularly high quality.

${ }^{50}$ Hinard 1999 suggests that this excerpt from the dissuasio of Catulus proves that Sulla resigned his dictatorship within the proper six-month term, possibly in time for the consular elections in July 81 for the following year.

${ }^{51}$ This is the phenomenon termed by Suetonius imperii consuetudo or 'habit of commanding': the psychological impact of extended periods of command, especially within the provinces, where poor communication and patchy senatorial oversight allowed the provincial governor essentially to rule alone in a far-flung corner of the empire. The best treatment of this is Eckstein 2004; for the thought of Dio on the destructive impact of imperii consuetudo in the Republic, see Burden-Strevens 2016.

${ }^{52}$ Cass. Dio 44.2.4: 'but for a city, not only so large in itself, but also ruling the finest and the greatest part of the known world...for such a city, I say, to practise moderation under a democracy is impossible'.
} 
It may not have been a morally appealing one either. Dio uses this speech to make a clever inversion of his first comments on the foundation of the dictatorship: desiring the beneficial aspects of a monarchy, the Romans in the wake of Tarquin originally 'chose it under another name'. But in the aftermath of the Sullan experiment, it is the name of dictatura, not monarchy, that the Romans cannot stomach. Now, having Q. Lutatius Catulus (the younger) advance the view that the Quirites 'cannot bear not only the function of a dictator but even the name' after Sulla is questionable. For a start, the speaker's own father had sided with Sulla, committing suicide rather than face Marius following the latter's occupation of Rome; and Catulus himself argued for the retention of the Sullan constitution during his consulship and an honourable burial upon his death. ${ }^{53} \mathrm{He}$ is not the most credible candidate to articulate these views of Dio. Melissa Barden Dowling has also suggested that there is no evidence that Sulla had yet entered political discourse as a negative exemplum by the time of this debate in 67 BCE, particularly in connection with cruelty or crudelitas; our earliest such citation seems to come in the late $60 \mathrm{~s}$ at In Catilinam 3.10..$^{54}$ But in fact these themes seem to have been explored as early as $80 \mathrm{BCE}$ in the Pro Roscio, albeit with only oblique reference to Sulla (for obvious reasons). ${ }^{55}$ Cicero mentions the recent dictator in revealingly fawning terms-'that most gallant and illustrious man, whom I only name to honour' $-{ }^{56}$ and directs his criticism toward his client and freedman Chrysogonus. But the disease of crudelitas is described in the peroration as endemic to the entire Republic and (significantly) as a recent phenomenon, 'having taken clemency away from the hearts of even merciful men, ${ }^{57}$ We are hard pressed not to think of Sulla, not least because his name is mentioned almost as much as Chrysogonus'-consistently either in extravagant rehearsal of the many reasons for which he could not possibly have been aware of his client's actions, or in the adulation which speaks of fear. ${ }^{58}$

Dio thus problematises the dictatorship in the Late Republic on two bases in the dissuasio of Catulus. Firstly, there is a practical consideration: a 'city which rules the world', in Dio's words, could not be governed democratically, and the demands of crisis within a wide empire necessarily required temporary returns to autocracy. Yet the conventional mechanism for such emergency measures-dictatorship-was not legally permissable within the existing framework, necessitating prolonged and corrosive periods of command. To my knowledge Dio is our only historian of this period to have given the dictatorship serious consideration in the failure of the Republic to manage its empire and as a practical justification for Augustus' rule. Secondly, there were moral concerns. If we give the words of Catulus any credence as a genuine attempt by the historian to portray his view of what people were thinking about dictatorship in the wake of Sulla-and allusions in the Pro Roscio might perhaps suggest an early origin for that kind of thought-then evidently Dio wished to argue that the dictatorship had come to be viewed as a toxic political solution. I have argued elsewhere that the set-piece orations, such as that of Catulus here, are the essential interpretative kernel of the Roman History. ${ }^{59}$ The choice to explore these two problems with the dictatorship-practical and reputational-thorugh a set-piece speech is entirely Dio's own. The office is unmentioned in his

\footnotetext{
${ }^{53}$ Q. Lutatius Catulus Major, suicide: Cic. Or. 3.9, Brut. 307, Tusc. 5.56; Diod. 38.4.2-3; Vell. Pat. 2.22.3-4; Val. Max 9.12.4; Plut. Mar. 44.8; App. B.Civ. 1.74. Q. Lutatius Catulus Minor, consulship: Sall. Hist. 1.47-48; App. B. Civ. 1.105.

${ }^{54}$ Barden Dowling 2000.

${ }^{55} \mathrm{I}$ am indebted to Prof. Catherine Steel (Glasgow) for bringing this to my attention.

${ }^{56}$ Cic. Rosc. 6.

${ }^{57}$ Cic. Rosc. 154.

${ }^{58}$ E.g. Cic. Rosc. 6, 21-22, 25-26, 110, 127, 130-131, 136, 143.

${ }^{59}$ Burden-Strevens 2015. It has at least long been recognised that the speeches are a window into Dio's thought, for which see Millar 1964, 79. Criticisms of Dio's tendency toward 'moralising' in the speeches (whose morals?) are often vague, e.g. Saylor Rogers 2006.
} 
source for the main arguments of Catulus' oration, ${ }^{60}$ and indeed in all parallel sources for the lex Gabinia of 67 BCE and the lex Manilia of the following year. ${ }^{61}$ Unprompted by an intermediary, Cassius Dio wished to problematise the dictatorship at this point because he considered it historically important at this 'turning-point' in the history of the Late Republic. ${ }^{62}$

Did contemporary Romans share these anxieties? Gianpaolo Urso has argued that the 'myth of Sulla' is in fact an Imperial phenomenon: there is no reason to suppose that the dictatorship had seriously come under scrutiny at this point in the Late Republic, especially if, with Francois Hinard, we accept that the dictator resigned appropriately within the six-month term. ${ }^{63}$ But Dio suggests differently, and contemporary evidence may support his claim. Let us return to the electoral crisis of 54-53 BCE. Cicero's letters I have already mentioned briefly as a source for the main events, although their interest for us here lies in their value as a source for attitudes. The letters to Quintus and Atticus between June and December 54 BCE suggest a growing atmosphere of suspicion and concern about rumours of a dictatorship, and these anxieties appear to be shared by a wider group than the orator alone. On June 3 Cicero writes to Quintus of 'some latent idea of a dictatorship' (erat aliqua suspicio dictaturae); but the rumours were unconfirmed, and in any case hopes for the resumption of proper comitia perhaps remained. ${ }^{64}$ By late October this hope was withering and the possibility of an interregnum arose: in that context Cicero speaks to Atticus of 'a whiff of dictatorship in the air, in fact a good deal of talk about it' (est non nullus odor dictaturae, sermo quidem multus). ${ }^{65} \mathrm{In}$ other letters from late October the tone is more panicked: Cicero puts Gabinius' acquittal in his trial for maiestas down to the 'fear-inducing rumour of a dictatorship' (dictaturae etiam rumor plenus timoris) ${ }^{66}$ Come November, Pompey seems to have been finally mentioned in explicit connection with such plans; it is only at this point at least that Cicero mentions his name. Cicero's claim that 'the rumour of a dictatorship is not pleasing to boni (rumor dictatoris iniucundus bonis) stresses questionable uniformity of opinion among a group to which he so often claimed to belong, although the difference in atmosphere is telling compared to June: 'the proposal, as a whole, is looked upon with alarm, and grows unpopular...there is nothing else being talked about in politics just now; at any rate, nothing else is being done' (sed tota res et timetur et refrigescit... aliud hoc tempore de re publica nihil loquebantur; agebatur quidem certe nihih) ${ }^{67}$ Finally, by December plans for a dictatorship for Pompey had definitely taken shape: 'Appius is intriguing darkly; Hirrus is paving the way' (Hirrus parat). Although Cicero notes indifference on the part of the people, it is the boni who again are alarmed at the prospect (populus non curat, principes nolunt). ${ }^{68}$

One possible way of approaching this material is to consider it not as evidence of alarmed attitudes toward the dictatorship as such in the $50 \mathrm{~s}$, but rather as a reflection on Pompey. This is a false dichotomy-it seems to me concerned with both-and in any case does not explain the reaction to rumours of a dictatorship between the early and late summer 54 which do not seem to have been in connection with Pompey's name. ${ }^{69}$ In Cicero's fulsome (and negative) accounts of Pompey's political activities throughout the summer in his epistles to

\footnotetext{
${ }^{60}$ Montecalvo 2014, 24-57 has shown that the historian drew the main arguments of Catulus' speech from the de Lege Manilia, where Cicero reports Catulus' and Hortensius' objections to Pompey's power. For further examples and a more assertive insistence that the historian was using the orator directly, see Burden-Strevens 2018.

${ }^{61}$ e.g. App. Mtih. 91-97; Plut. Pomp. 25.10; Sall. Hist. 5.20-24M: Val. Max. 8.15.9; Vell. Pat. 2.32.1-3.

${ }^{62}$ So described by Coudry 2016.

${ }^{63}$ Hinard 1999, rejected by Ramsey 2016310 n. 44; Urso 2016.

${ }^{64}$ Cic. Q. Fr. 2.13.5.

${ }^{65}$ Cic. Q. Att. 4.18.3.

${ }^{66}$ Cic. Q. Fr. 3.4.1.

${ }^{67}$ Cic. Q. Fr. 3.8.4-6.

${ }^{68}$ Cic. Q. Fr. 3.9.3.

${ }^{69}$ So Cic. Att. 4.18.3, Q. Fr. 3.4.1.
} 
Quintus and Atticus, all manner of infractions are recorded. ${ }^{70}$ Yet Pompey's name is nowhere in connection with a possible dictatorship until November; all Cicero records prior to that, possibly in June and certainly by October, is fearful rumours of a possible nomination. Given Cicero's distaste for Magnus noster in the letters of this period and the detail he provides on his activities, the absence of his name is surprising. I would (cautiously) suggest that Pompey was not at the centre of rumours of a possible dictatorship until late in the year; Plutarch and Dio date this as late as C. Lucilius Hirrus' election to the tribunate in December, but this is too late. $^{71}$ The anxiety perhaps in June and certainly October is about a dictatorship as such, and not only Pompey.

Relying solely on Cicero for this picture is perilous, but can fortunately be supplemented. The evidence of coinage is controversial, but remarkably under-studied in connection with contemporary attitudes to the dictatorship, and never in conversation with Dio's history. ${ }^{72}$ Like the letters, the numismatic material can be revealing of the opinions not only of their producer but also of messages he expected those who mattered to accept. If we wish to gauge the veracity of Dio's view that the dictatorship per se had become politically toxic in the Late Republic then three denarii from the 50s are of especial interest. The first we turn to is certainly the latest and easiest to date, minted shortly after the consuls for 53 finally entered office in the summer. The moneyer is M. Valerius Messalla, ${ }^{73}$ son of the newly-elected consul Messalla Rufus. The obverse is perfectly conventional, hence the obverse legend (MESSAL-F) right and downwards of the helmeted head of Roma. But the reverse is extraordinary. Two curule chairs, flanked by S. C. (SENATV CONSVLTO) on either side, celebrate the successful resumption of Republican magistracies and senatorial integrity: this message is reinforced with PATRE.COS above. Beneath there lies (probably) a horizontal sceptre and certainly a diadem, a circular strip of fabric with a knot and two tails: the characteristic trapping of Hellenistic kingship. ${ }^{74}$ The choice of images is deliberate and significant: the proper framework of regular magistracies triumphs over tyrannical regnum-or, in a Republican context, over recently thwarted plans for a dictatorship. In Crawford's words, the reverse type 'portrays the subjection of the attributes of royalty to that of Republican legality; it reflects the (temporary) exclusion of Pompey from the possibility of achieving sole rule. ${ }^{75}$ This was not the first time that Pompey was compared to a Hellenistic king: in 56 BCE the aedile Favonius quipped, upon seeing a white bandage attached to his leg, that it made little difference where on his body the diadem sat. ${ }^{76}$ Although the trappings of the Hellenistic king are not categorically 'tyrannical'-Classical tyranny is an ethical, not iconographical, phenomenon-Republican political invective does not recognise that distinction. A Roman statesman who dresses and acts like a king is always a tyrant.

\footnotetext{
${ }^{70}$ Cic. Att. 4.15 (27 July), Q. Fr. 3.1 (28 September), 3.2 (October), 3.3 (October), 3.4 (24 October).

${ }^{71}$ Plut. Pomp. 54.2; Cass. Dio 40.45.5.

${ }^{72}$ To my knowledge only one Republican coin is ever discussed in connection with the Roman History: the famous silver denarius of Brutus of the EID MAR type, mentioned at Cass. Dio 47.25 (RRC 502/4). See Cahn 1988 211-232 for a more recent die study of the issue.

${ }^{73}$ On his post as triumvir monetalis in this year, see Syme 1986, 228.

${ }^{74}$ On the diadem, see Carson 1957, 50-52 and Rawson 1975, 150. Scepticism that the reverse type portrays a diadem is peculiar: for roughly contemporary Roman types one need only compare with RRC 507/2 or for genuine Hellenistic examples the diademed heads of Philip V (e.g. SNG München 1124, SNG Alpha Bank 1049, $A M N G$ III 2).

${ }^{75}$ Crawford 1974, 457.

${ }^{76}$ Val. Max. 6.2.7: cui candida fascia crus alligatum habenti Fauonius 'non refert' inquit 'qua in parte sit corporis diadema'.
} 


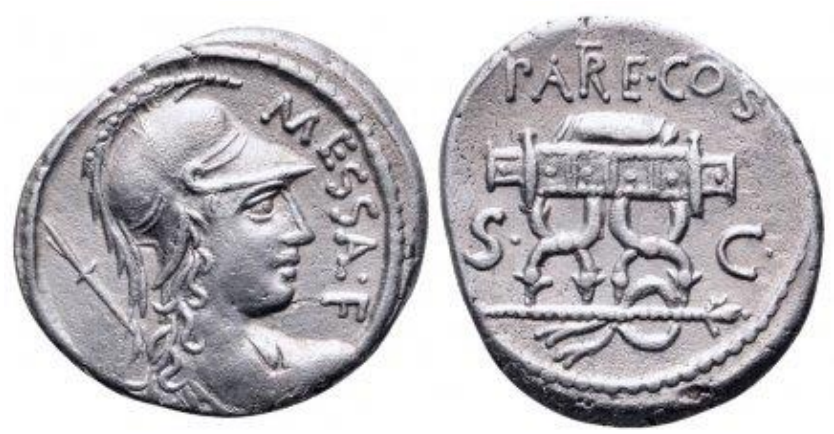

Fig. 1: Republican denarius, 53 BCE (RRC 435/1)

Here we should remember the disagreement between our literary sources. We have already seen that Appian, Plutarch, and Cicero all suggest that Pompey was manoeuvring deliberately toward a dictatorship; his plans were only thwarted by Cato and Bibulus. ${ }^{77}$ But Cassius Dio maintains that he voluntarily declined it and took pains to get consuls elected for 53-'since in remembrance of Sulla's cruelty all hated that office'. ${ }^{78}$ Messalla's denarius does seem to sit ill with Dio's interpretation of Pompey's motivations-evidently a broader contingent than only Cicero were concerned about the general's plans. But at the same time, it supports his overall view about contemporary attitudes to the dictatorship, and so emphasises Pompey's political acumen in refusing the office. We have to remember that controversial and (to many) alarming plans for a dictatorship have just been scotched. The choice of images-the sceptre and diadem of a Hellenistic king, subordinated by the symbols of consular and senatorial authority-needs to be interpreted in that context. Andreas Kalyvas has argued that it is our Greek historians of the Republic, Dionysius and Appian, who first conceived of a relationship between the Roman dictatorship and Greek tyranny: they began a trend for critiquing the dictatorship using words and concepts borrowed from the Greek tradition. ${ }^{79}$ This development in fact has earlier roots: this language is certainly identifiable in the events of $53 \mathrm{BCE}$, and it is Roman statesmen-not Greek historians-who were using that language.

The message of consular legitimacy in opposition to tyrannical rule appears in other numismatic evidence from the 50s. This may, or may not, be in connection with the electoral crisis and rumours of a dictatorship, depending on how we date the material. The coinage of M. Brutus furnishes some particularly well-known types. In the first, the obverse displays a personification of Libertas, right-facing with the legend downward and behind (LIBERTAS). The reverse features a procession of four individuals: the second and fourth in the quartet are evidently lictors carrying fasces, flanking a slightly larger figure on either side. The identification of this larger figure as L. Junius Brutus, the first Roman consul after the alleged expulsion of the Tarquins, is aided by the text in exergue: BRVTVS, identifying both the minter of the coin and the subject of the reverse type. The general themes and the interaction between those themes are quite clear: the eradication of tyranny from the state and its replacement by the Republican magistracies, especially the consulship, standing as the guarantee of libertas (or at least an optimate interpretation of it). ${ }^{80}$ These messages are replicated in a second well-known issue from the year of Brutus' moneyership: L. Junius Brutus returns again on the obverse, right-facing with the legend BRVTVS downward and behind; the reverse features a portrait of $\mathrm{P}$. Servilius Ahala, who in Republican mytho-history killed Sp. Maelius in 439 BCE to prevent his attempt to seize power.

\footnotetext{
${ }^{77}$ App. B.Civ. 2.23.1; Plut. Pomp. 54.3; Cic. Q. Fr. 3.8.5.

${ }^{78}$ Cass. Dio 40.46, 40.50.

${ }^{79}$ Kalyvas 2007. Particularly important passages are App. B.Civ. 1.99, 1.101 and D.H. AR 5.70, 5.73.

${ }^{80}$ Arena 2012, 1-13.
} 

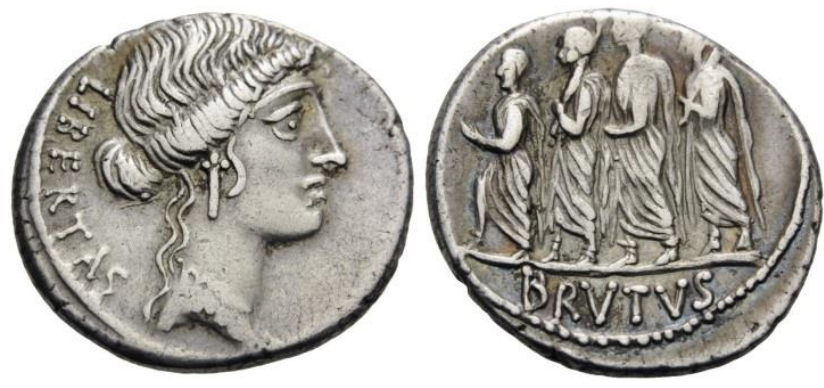

Fig. 2: Republican denarius, 54 BCE? (RRC 433/1)
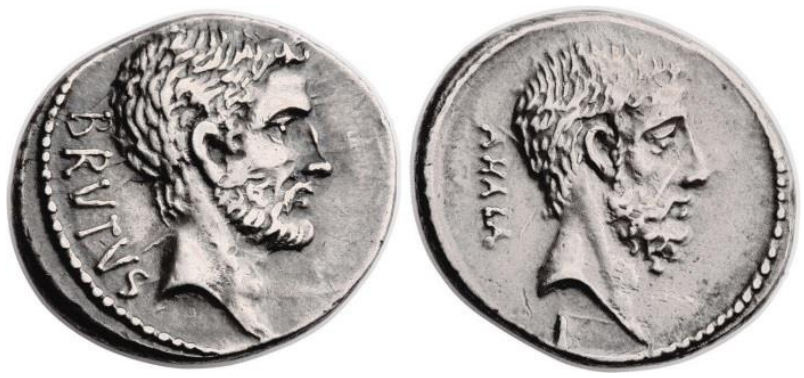

Fig. 3: Republican denarius, 54 BCE? (RRC 433/2)

The themes present in Brutus' coinage are of course especially relevant to 54-53, where the collapse of the consular elections left the way open for a dictatorship that many-not only Cicero-seem to have feared. The allusion to L. Junius Brutus, the expulsion of the Tarquins, and the institution of the consulship are telling in this context. However, the dating and interpretation of these coins is a subject of much debate. Michael Crawford suggests 54 BCE, viewing these issues as as 'part of a pattern of consistent opposition to Pompey's real or supposed intentions of achieving sole rule'; Matthew Rockman among others has retained this dating and interpretation on the basis of events in that year. ${ }^{81}$ But an alternative view is that Brutus' term as triumvir monetalis occurred a year earlier than previously thought and that these issues therefore date to $55 \mathrm{BCE}$, before the electoral and dictatorship débacle. ${ }^{82}$ This argument is persuasive, although Cerutti goes too far in radically claiming that Brutus' sole intention in minting these coins was to advertise his family lineage and that they are silent on political events. ${ }^{83}$ There is no room here to wade into this debate. But evidently these issues, which were produced some time in the $50 \mathrm{~s}$ in or before $54 \mathrm{BCE}$, evince a distinct range of political concerns: anxieties about tyranny and adfectatio regni, concern for the proper functioning of Republican magistracies, and arguments for the protection of traditional liberty.

The analysis that Dio offers, through Catulus, of the problem with the dictatorship in the final decades of the Republic is intriguing. He believed that the Quirites of this period had grown averse to the dictatorship as a toxic and discredited political institution. For a 'living' articulation of that view in a specific context he used Catulus in Book 36-though of course Dio makes clear in his own commentary on the lex Antonia that the office itself was not problematic, merely the perception of it. In Dio-and indeed, only in Dio-does Pompey seem aware of these problems, and accounts for them in his decision to decline the honour. This interpretation merits our consideration for three reasons. Firstly, Dio was right. Contemporary evidence testifies to the atmosphere of anxiety in 54 surrounding plans for a dictatorship, and the earlier examples (such as Cicero's letters from June and October) may suggest that those anxieties were directed toward a dictatorship as such rather than merely toward Pompey. Secondly, Dio is to my knowledge unique in considering the practical limitations of the dictatorship as a causal factor in the proliferation of extraordinary commands that were corrosive to Republican traditions. Why else insert this point in the debates surrounding the lex Gabinia of 67 BCE, which seems wholly irrelevant otherwise? In Dio's view at least, the Quirites had no other choice than Pompey for precisely the reasons his Catulus outlines. Third and

\footnotetext{
${ }^{81}$ Crawford 1974, 455; Rockman 1992, 14; also Hersh \& Walker 1984 and De Rose Evans 1992, 146; the latter with a revised date of 59 BCE. The chronology of the coin hoards provided by Cerutti 1993, 71-72 shows that these issues must have been minted no later than 54 BCE.

${ }^{82}$ Cerutti 1993 passim.

${ }^{83}$ Pace Cerutti 1993, 80: "there is no evidence to support the claim that Brutus's two coin types were intended to allude to anything more than his ancestors' historical achievements".
} 
finally, our historian's critique of the dictatorship is an important part of his explanation of and justification for Augustus' rule. And for that we must turn to some final comments.

\section{THE FINAL PHASE: FINDING A REPLACEMENT}

In 22 BCE a period of pestilence and famine struck Rome, five years after the Augustan 'Settlement' lavishly detailed in Books 52-53. According to Dio the starving plebs were convinced that the only answer to the crisis was to beg Augustus to assume the dictatorship and the cura annonae: both of these had been abolished as unconstitutional within a single year two decades previously. After shutting up the Senate in the curia and (allegedly) threatening to burn it down-a recurring formula in Dio's history ${ }^{81}-$ the people presented their demands:

They took the twenty-four fasces and approached Augustus, begging him to consent to be made dictator as well as curator of the grain-supply, just as Pompey had once

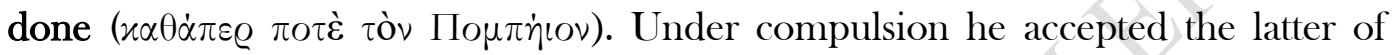
these, and ordered that two men be chosen each year from among those who had served as praetors at least five years previously, so as to see to the distribution of

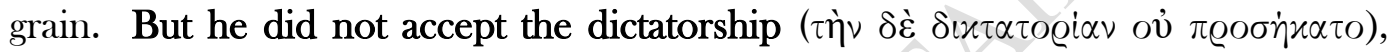
and indeed rent his clothes when he could find no way of convincing the people otherwise, either by argument or begging. For as he already had power and honour in excess of the dictators anyway, he rightly guarded against the envy and hatred that

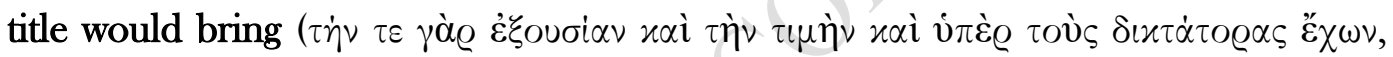

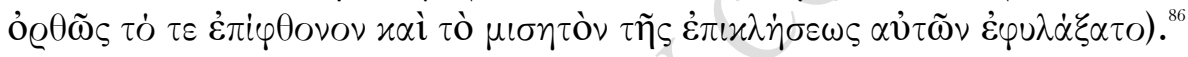

Dio's is the most detailed account that we have of this incident. Suetonius gives a short sentence stating the basic facts; ${ }^{87}$ Velleius Paterculus provides the same information in a fawning oneliner. ${ }^{88}$ Augustus also briefly records the event himself: tellingly, he considered his public disavowal of a dictatorship one of his many proud distinctions. ${ }^{89}$ But our historian is much fuller. He used this moment not only (like the Res Gestae) to emphasise Augustus' civilitas and refusal to aggrandise himself with further honours, but also emphasises its constitutional significance. Dio's princeps had no need of a dictatorship, since his power and honour

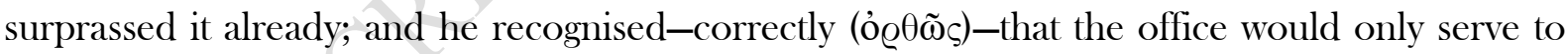
tarnish his reputation and bring him into suspicion. In other words, the historian partly interprets Augustus' success in managing his constitutional image through the lens of the dictatorship. We are reminded of the foreshadowing of Caesar in the historian's commentary on the earliest foundation of that office; Dio's Augustus does not repeat Caesar's mistake.

For Dio this mistake was not one of the reality of Caesar's power, but rather its presentation. The historian himself clearly did not believe that Caesar's rule was tyrannical. Far from it: he writes that those who plotted against him were motivated not by his faults, but from fear that his 'goodness' ( $\tau \dot{\eta} \vee ~ \chi \varrho \eta \sigma \tau \dot{\tau} \tau \tau \tau \alpha \alpha \dot{v} \tau o \tilde{v})$ would not last. ${ }^{90}$ His generosity and clemency

\footnotetext{
${ }^{84}$ Libourel 1974.

${ }^{85}$ Cass. Dio 54.2.1-5 for the entire narrative of the episode.

${ }^{86}$ Note the similarity between this final idea and Pompey's attitude to the consulship sine collega at Cass. Dio

40.51.1, discussed above. Pompey, not Caesar, is the model for Augustus in the Roman History.

${ }^{87}$ Suet. Aug. 52.

${ }^{88}$ Vell. Pat. 2.89.5.

${ }^{89}$ Aug. RG5.

${ }^{90}$ Cass. Dio 42.27.4.
} 
put Sulla's cruelty to shame..$^{91}$ The dictator was, in Dio's presentation, a scheming vulture, pleonectic and wastrel at the same time, who absolutely aspired to kingship. ${ }^{92}$ But he was no tyrant. Nevertheless, Dio's Caesar fails to understand the importance of appearances. He adopted the attire of the ancient kings of Alba, and a golden chair and crown set with jewels was to be carried into theatres, among other honours. ${ }^{93}$ He allowed himself to grow conceited and puffed-up-and this, in Dio's view, is precisely what his enemies wanted: 'the majority followed this course because they wished to make him envied and hated as quickly as possible, that he might the sooner perish'. ${ }^{94}$

Augustus made no such error. His refusal of the dictatorship reiterates his political acumen: he is made to recognise the importance of the terms with which power is defined. Naturally that of 'dictator' had become completely unpalatable. We have seen Dio's argument that it had in fact been so for many years, long before Caesar mistakenly adopted it; it was neither a practical nor attractive solution to the crisis surrounding the lex Gabinia, for example. Yet Dio believed that monarchy was absolutely essential for any stable state. When dictatorship failed, the libera res publica failed: Rome's recourse to a temporary monarchy had to be replaced. The answer lay in Octavian's rebirth as 'Augustus' and princeps: a position of power greater than the dictator's which eschewed the 'envy and hatred the title would bring' ( $\tau \dot{0} \tau \varepsilon$

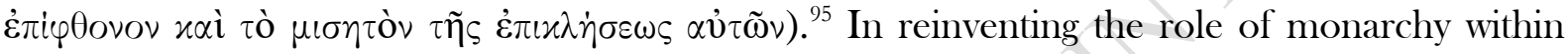
the state-a monarchy under a civil guise-and rejecting the discredited position of dictator, Dio's Augustus is in fact following the advice of Maecenas in Book 52, which explains the historian's view in explicit terms: ${ }^{96}$

If you really do desire the reality of monarchy but fear the name of it as an accursed thing, then decline the title of 'king' and rule alone under the title of 'Caesar'. But if you come to require other epithets, then the people will give you the title of imperator, just as they gave it to your father; and they will revere you with another

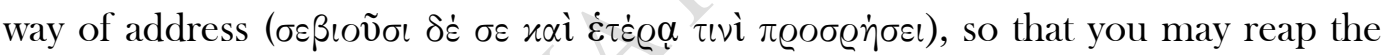
crop of the reality of kingship without the odium which attaches to the name of 'king'.

On the one hand Maecenas' prediction that the Romans will 'revere' Octavian with a new name

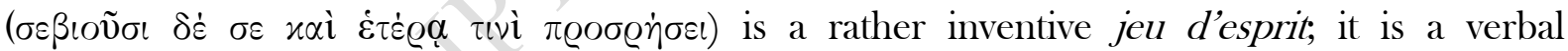
foreshadowing of the princeps'new title of Augustus, or $\sigma \varepsilon \beta \alpha \sigma \tau$ c่.

But the rhetorical flair should not disguise the real force of this passage within Cassius Dio's argument about the transformation of dictatorship in the Late Republic, its problems, and its replacement by the Augustan Principate. From its earliest mention in the Roman History Dio sought to explore the dictatorship in a way distinctive within the historiography of the Republic. In keeping with his theoretical view of the weakness of democracy and the necessity of monarchy-particularly for a 'city which rules the world'-Dio viewed dictatorship as a beneficial return to the best that monarchy had to offer. Describing it in terms reminiscent of Cicero's Republic, Dio resisted the temptation succumbed to by Dionysius, and to a lesser extent Livy, to view that office from its very inception through the prism of events in the $1^{\text {st }}$ century BCE; less still to describe it simplistically as a form of tyranny. Rather, Dio (paradoxically) believed that a successful democracy required a viable resort to monarchy in

\footnotetext{
${ }^{91}$ Cass. Dio 43.50.2.

${ }^{92}$ Cass. Dio 44.11.1.

${ }^{93}$ Cass. Dio 44.6.1-4.

${ }^{94}$ Cass. Dio 44.7.3.

${ }^{95}$ Cass. Dio 54.1.5.

${ }^{96}$ Cass. Dio 52.40.1-2.
} 
times of crisis. In the Late Republic that vision collapsed. When pressed with crisis in the Mediterranean in 67 BCE the Quirites could not call on their traditional offices for practical and moral reasons: Rome's emergency powers had not kept pace with the growth of empire, and in any case the dictatorship was a discredited solution. The disastrous alternative-Dio's Catulus warns-would be further extraordinary commands, and Pompey. Thirteen years later when Republican institutions had entirely broken down, Dio records continuing aversion to the dictatorship, 'since in remembrance of Sulla's cruelty all hated that office'. ${ }^{97}$ The again disastrous alternative was a sole consulship for Pompey in 52 BCE.

For Dio the failure of the dictatorship precipitated the failure of the Republic itself. We may find this outlandish. But concerns about a dictatorship in the electoral crisis of 54-53 BCE were evidently widespread, at least among the boni; these were articulated in the the language of traditional liberty, privileging the dyarchy of consuls in conversation with the Senate and emphasising the rejection of tyranny. Cassius Dio himself believed that such concerns were mistaken: the dictatorship itself was not the problem, merely the toxic combination of military force and an autocratic character. It is testament to his quality as an historian that he explains the actions of his historical characters, such as the Romans who voted for the lex Antonia, with rationales that he himself did not accept. Dio often resists the temptation to project his own views onto his actors. In Catulus in 67 or Cato and Bibulus in 53, we see individuals acting not as agents of Dio's hindsight, but as Republican statesmen whose proximity to events blinds them to the nature of the problem, and who pose ineffective and ultimately catastrophic solutions for their predicament.

In the end, Dio's Augustus understood both the necessity of monarchy and the need to redefine it. To paraphrase the preface to Tacitus' Annals, he realised that he should be neither king nor dictator, but princeps. ${ }^{98}$ His disavowal of the dictatorship in 22 BCE has its precedent in Pompey's refusal thirty years earlier; yet to Dio, Augustus' refusal-again like Pompey's-was not merely a show of recusatio imperii, much as it may have filled that additional purpose. Rather, it was an astute realisation of the political reality, and a fulfilment of Maecenas' suggestion to cloak the fact of monarchy under new and acceptable titles. Here as so often in the Roman History, it pays to follow Maecenas' advice.

\footnotetext{
${ }^{97}$ Cass. Dio 40.45.5.

${ }^{98}$ Tac. Ann. 1.1.
} 


\section{Works Cited}

Arena, V. Libertas and the Practice of Politics in the Late Roman Republic (Cambridge: Cambridge University Press, 2012).

Barden Dowling, M. 'The Clemency of Sulla'. Historia 49/3 (2000): 303-340.

Burden-Strevens, C.Cassius Dio's Speeches \& the Collapse of the Roman Republic (Diss. Glasgow, 2015).

Burden-Strevens, C. 'Fictitious Speeches, Envy, \& the Habituation to Authority: Writing the Collapse of the Roman Republic' in Lange, C. H. \& Madsen, J. M. (eds.), Cassius Dio-Greek Intellectual and Roman Politician (Leiden: Brill, 2016): 193-216.

Burden-Strevens, C. (2018) 'Reconstructing Republican Oratory in Cassius Dio's Roman History' in Gray, C., Balbo, A., Marhall, R. M. A. \& Steel, C. E. W. (eds.), Reading Republican Oratory: Reconstructions, Contexts, Receptions (Oxford: Oxford University Press 2018): 111-134.

Cahn, H. 'EIDibus MARtiis', NumAntClas 18 (1988): 211-232.

Carson, R. 'Caesar and the Monarchy'. G\& R 4/1 (1957): 46-53.

Cerutti, S. (1993) 'Brutus, Cyprus, and the Coinage of 55 B.C.' AJN5/6 (1993-4): 69-87.

Cornell, T. The Beginnings of Rome: Italy and Rome from the Bronze Age to the Punic Wars (London: Routledge, 1995).

Coudry, M. 'Cassius Dio on Pompey's Extraordinary Commands' in Lange, C. H. \& Madsen, J. M. (eds.), Cassius Dio-Greek Intellectual and Roman Politician (Leiden: Brill, 2016): 33-50.

Crawford, M. The Roman Republican Coinage, Volume 2 (Cambridge: Cambridge University Press, 1974).

DeRose Evans, J. The Art of Persuasion: Political Propaganda from Aeneas to Brutus (Ann Arbor: The University of Michigan Press, 1992).

Eckstein, A. 'From the Historical Caesar to the Spectre of Caesarism: The Imperial Administrator as Internal Threat' in Baehr, P. \& Richter, M. (eds.), Dictatorship in History and Theory (Cambridge: Cambridge University Press, 2004): 279-298.

Forsythe, G. A Critical History of Early Rome. From Prehistory to the First Punic War (Berkeley: University of California Press, 2005).

Fromentin, V. 'La fiabilité de Zonaras dans les deux premières décades de l'Histoire romaine de Cassius Dion: le cas des discours' in Burden-Strevens, C. \& Lindholmer, M. (eds.), Cassius Dio’s Forgotten History of Early Rome (Leiden: Brill, forthcoming 2018).

Gowing, A. The Triumviral Narratives of Appian and Cassius Dio (Ann Arbor: The University of Michigan Press, 1992). 
Gruen E. 'The Consular Elections for 53 B.C.', in Bibauw J. (ed.), Hommages à Marcel Renard II (Brussels, 1969): 311-21.

Hersh, C. \& Walker, A. 'The Messagne Hoard', ANSMN 29 (1984): 103-134.

Hinard, F. 'Dion Cassius et l'abdication de Sylla'. REA 101 (1999) : 427-432.

Kalyvas, A. 'The Tyranny of Dictatorship: When the Greek Tyrant Met the Roman Dictator'. Political Theory 35/4 (2007): 412-442.

Libourel, J. 'An Unusual Annalistic Source Used by Dio Cassius.' AJPh 95 (1974): 383-393.

Lintott, A. The Constitution of the Roman Republic (Oxford: Oxford University Press, 1999).

Madsen, J. 'Criticising the Benefactors: The Severans and the Return of Dynastic Rule' in Lange, C. H. \& Madsen, J. M. (eds.), Cassius Dio-Greek Intellectual and Roman Politician (Leiden: Brill, 2016): 136-158.

Mallan, C. 'The Regal Period in the Excerpta Constantiniana and in some Early Byzantine Extracts from Dio's Roman History' in Burden-Strevens, C. \& Lindholmer, M. (eds.), Cassius Dio’s Forgotten History of Early Rome (Leiden: Brill, forthcoming 2018).

Meier, C. Res Publica Amissa. Eine Studie zu Verfassung und Geschichte der späten römischen Republik (Wiesbaden, 1966).

Meyer, E. Caesars Monarchie und das Principat des Pompejus. $3^{\text {rd }}$ edition (Berlin, 1922).

Millar, F. A Study of Cassius Dio (Oxford: Clarendon Press, 1964).

Ramsey, J.T. 'How and why was Pompey made sole consul in 52 BC?'. Historia 65/3 (2016): 298-324.

Rawson, E. 'Caesar's Heritage: Hellenistic Kings and their Roman Equals'. JRS 65 (1975) : 148-159.

Rilinger, R. 'Die Interpretation des Niedergangs der römischen Republik durch 'Revolution' und 'Krise ohne Alternative' in Rilinger, R. (ed.), Ordo und Dignitas. Beiträge zur römischen Verfassungs- und Sozialgeschichte (Stuttgart, 2007): 123-150.

Rockman, M. 'The Coins of the Roman Republic from 60 to 50 B.C: Another Look at chronology'. The Celator 6/2 (1992): 8-14.

Saylor Rogers, B. 'Catulus' Speech in Cassius Dio 36.31-36'. GBRS 48 (2006): 295-318.

Simons, B. Cassius Dio und die Römische Republik (Berlin: de Gruyter, 2009).

Steel, C. E. W. The End of the Roman Republic: Conquest and Crisis (Edinburgh: Edinburgh University Press, 2013). 
Syme, R. The Augustan Aristocracy (Oxford: Clarendon Press, 1986).

Urso, G. 'Cassius Dio's Sulla: Exemplum of Cruelty and Republican Dictator' in Lange, C. H. \& Madsen, J. M. (eds.), Cassius Dio-Greek Intellectual and Roman Politician (Leiden: Brill, 2016): 13-32.

Zarecki, J. Cicero's Ideal Statesman in Theory and Practice (Bloomsbury: London \& New York, 2014). 